\title{
Distributional records for three little-known and rare flowering plants from West Bengal, India
}

\author{
K. Ravikumar ${ }^{2}$, N. Dhatchanamoorthy, W. Arisdason ${ }^{1}$ and D. Saha \\ Centre for Conservation of Natural Resources, The University of Trans-Disciplinary Health Sciences and \\ Technology (TDU), Foundation for Revitalisation of Local Health Traditions (FRLHT), No. 74/2, \\ Jarakabande Kaval, Attur Post, Yelahanka Via, Bangalore - 560 064, Karnataka, India. \\ ${ }^{1}$ Botanical Survey of India, Southern Regional Centre, TNAU Campus, Lawley Road, Coimbatore - 641 \\ 003, Tamil Nadu, India. \\ ${ }^{2}$ Corresponding author, e-mail: ravikumarfrlht@gmail.com
}

[Received 02.06.2019; Revised \& accepted 28.06.2019; Published 30.06.2019]

\begin{abstract}
Three angiospermic taxa, Ixora anthroantha Bremek. (Rubiaceae), Psychotria erratica var. pedunculata Hook.f. (Rubiaceae) and Peliosanthes violacea var. minor Baker (Asparagaceae) have been collected from thr North Sevoke Medicinal Plants Conservation Area located at the feet of Darjeeling Hills, West Bengal, India during 2017. These are now reported here as first record of occurrence for the state of West Bengal.
\end{abstract}

Key words: Ixora anthroantha, Psychotria erratica var. Pedunculata, Peliosanthes violacea var. Minor, New record, Flora, West Bengal

\section{INTRODUCTION}

The North Sevoke Medicinal Plants Conservation Area (NSMPCA), one among the seven Medicinal Plants Conservation Areas in the state of West Bengal, is situated in Darjeeling district. The central location of the conservatory is $26^{\circ} 52^{\prime} \mathrm{N}$ Longitude and $88^{\circ} 27^{\prime}$ E Latitude and covers an area of 100 ha. The MPCA supports 'North India Moist Deciduous Forests' (Champion \& Seth 1968). While exploring the flowering plant wealth of MPCA three flowering plant species viz., Ixora anthroantha (Rubiaceae), Psychotria erratica var. pedunculata (Rubiaceae) and Peliosanthes violacea var. minor (Asparagaceae) have been collected. The identity of all three species was confirmed on careful examination of fresh plant materials along with perusal of relevant literature (Hooker 1880; Jessop 1976; Deb \& Gangopadhyay 1989; Husain \& Paul 1989; Roy 2018). Among the three taxa, Psychotria erratica var. pedunculata and Peliosanthes violacea var. minor are reported here as additions to the angiospermous flora of West Bengal State and for Ixora anthroantha the fruits are described here for the first time. For each taxon description, flowering and fruiting period, habitat with plant association, differences with close allies, distribution, notes on occurrence and population, photographs of plants are provided herewith.

\section{ENUMERATION}

1. Ixora anthroantha Bremek., Indian Forester 85(7): 372. 1959; T. Husain \& S.R. Paul, J. Econ. Taxon. Bot., Addit. Ser. 6: 109, f. 16. 1989. [RUBIACEAE]. [PLATE - I, Figure 1 $\mathbf{a}-\mathbf{c}]$.

Shrub, to $3.5 \mathrm{~m}$ high; branches terete, angled; stems hollow, glabrous and shiny. Leaves opposite, broadly elliptic-lanceolate to oblong-oblonceolate, $13-38 \times 4.5-13.5(-20.5)$, entire, acute- 
acuminate, cuneate or obliquely cuneate at base, glabrous above, with black sessile glands on lower surface; lateral veins $c .22$ pairs; petioles $c .5 .2 \mathrm{~cm}$ long, triangular, thick, broadened at base, glabrous. Infructescence in terminal pedunculate umbels, $5.5-6.5 \mathrm{~cm}$ long; peduncles angled or terete, to $3 \mathrm{~cm}$ long, densely pubescent, brownish; primary pedicels angled, to $1 \mathrm{~cm}$ long, appressed-pubescent; secondary pedicels terete or angled, 5-7 mm long; bracts linearlanceolate, $5-9 \mathrm{~mm}$ long, acuminate at apex, sparsely pubescent, brownish; bracteoles linear, $3-4 \mathrm{~mm}$, sparsely appressed-pubescence. Calyx 5-lobed; tube $c .2 \mathrm{~mm}$ long, minutely hairy or glabrous; lobes linear-triangular, $c .1 \mathrm{~mm}$ long, acuminate at apex. Fruits ovoid-globoid, 1 or 2-lobed, 9-18 $\times 6-10 \mathrm{~mm}$, persistent with calyx-rim at apex, brownish black when dry, hard; seeds 1 or 2, subglobose-ellipsoid, c. $7 \times 3 \mathrm{~mm}$ long, yellowish.

Fruiting: October - December.

Ecology: It is found occasionally in the Moist Deciduous Forest and is known from a single locality with only two mature individuals and the area of occupancy is estimated to be 10 $\mathrm{km}^{2}$. This species is associated with Hedyotis scandens Roxb., Hiptage benghalensis (L.) Kurz, Jasminum flexile Vahl, Lepidagathis incurva Buch.-Ham. ex D.Don, Pavetta indica L., Pericampylus incanus (Colebr.) Miers ex Hook.f. \& Thomson, Phlogacanthus thyrsiformis (Roxb. ex Hadrw.) Mabb., Piper attenuatum Buch.-Ham. ex Miq., Pueraria sikkimensis Prain, Smilax griffithii A.DC., Strobilanthes sp. and Tabernaemontana divaricata (L.) R. Br. ex Roem. \& Schult.

Distribution: India (Assam, West Bengal) and Bangladesh.

Specimens examined: INDIA: West Bengal, Darjeeling district, Sukna, May 1940, M.V. Laurie s.n. (DD); North Sevoke MPCA, 177 m, 24.10.2017, K. Ravikumar \& N. Dhatchanamoorthy 121981 (FRLH).

Note: Bremekamp (1959) described I. anthroantha without fruits, and stated fruits not yet seen. However, during the present study, the plants were found in fruiting state, and hence the morphological features of fruits and seeds are provided.

This species closely resembles I. acuminata Roxb., but can easily be distinguished from the latter by having anthers with filaments (vs. sessile anthers) and absence of wax layer on ovary (vs. ovary covered with wax layer).

2. Psychotria erratica Hook.f. var. pedunculata Hook.f., Fl. Brit. India 3: 169. 1880; Deb \& M. Gangop., J. Econ. Taxon. Bot., Addit. Ser. 7: 103, f. 40. 1989. [RUBIACEAE] [PLATE - I, Figure 2 a - c]

Shrub, $1-1.5 \mathrm{~m}$ high; young branches sparsely appressed-puberulous, glabrous on maturity. Leaves opposite, elliptic-lanceolate, $9-13.2 \times 3.3-5.8 \mathrm{~cm}$, entire, acute-acuminate, narrowly cuneate at base, glabrous above, sparsely appressed-puberulous and sessile glandular beneath, brownish; lateral veins $c$. 12 pairs, brownish beneath; petioles $1-2 \mathrm{~cm}$ long, striate, appressedpuberulous, brownish when dry. Stipules ovate, c. $2 \mathrm{~mm}$ long, acute-acuminate at apex, 2 or 3-lobed, minutely appressed puberulous or pubescent beneath or glabrous. Infructescence axillary or rarely terminal; dichotomously pedunculate cymes; primary peduncles slender, striate, to $4.7 \mathrm{~cm}$ long; secondary peduncles to $9 \mathrm{~mm}$ long, glandular-pubescent; pedicles 3 angled, to $5 \mathrm{~mm}$ long, glandular-pubescent. Bracts 2 or 3-lobed, ovate-triangular, $5-10 \mathrm{~mm}$ long, lateral lobes acute at apex, middle lobes acuminate at apex, pubescent; bracteoles lanceolate, $2-5 \mathrm{~mm}$ long, acuminate at apex, appressed-puberulous or glabrous. Fruits ovoid-globose, $5-7$-ridged, glabrous, thick, $5-7 \times c .3 .5 \mathrm{~mm}$ long.

Fruiting: October - December. 
200 New record of three species for West Bengal
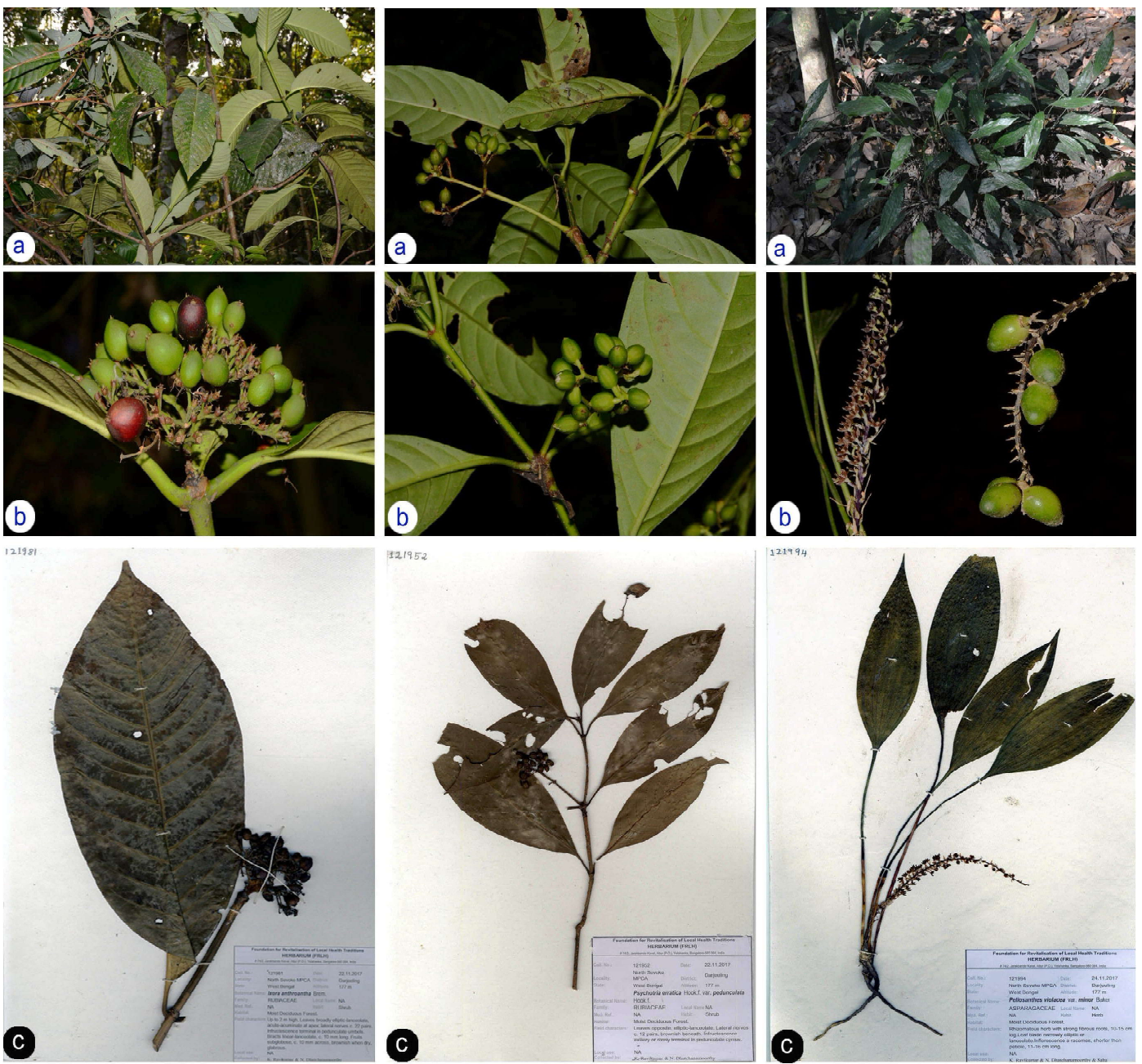

PLATE - I. 1. Ixora anthroantha a. Habit, b. Infructescence, c. Herbarium sheet; 2. Psychotria erratica var. pedunculata a. \& b. Infructescences, c. Herbarium sheet; 3. Peliosanthes violacea var. minor a. Habit, b. Flowers \& Fruits, c. Herbarium sheet

Habitat: It is found occasionally in the Moist Deciduous Forest; growing with Aristolochia indica L., Ageratum conyzoides (L.) L., Coffea bengalensis Roxb. ex Schult., Cyanthillium cinereum (L.) H. Rob, Elephantopus scaber L., Oplismenus compositus (L.) P.Beauv., Persicaria hydropiper (L.) Delarbre, Piper attenuatum Buch.-Ham. ex Miq. and Smilax zeylanica L.

Distribution: WORLD: Bhutan, Nepal and India (Sikkim, West Bengal)

Specimens examined: INDIA: West Bengal, Siliguri, Darjeeling district, Moist Deciduous Forest of North Sevoke MPCA, 177 m, 22.11.2017, K. Ravikumar \& N. Dhatchanamoorthy 121952 (FRLH).

Additional specimens examined: Type: West Bengal, Sukna, May 1940, M. V. Laurie $s$. n. (DD!). Assam, Ledo, April, 1935, D.E. Bernard 21 (BM!).

Note: Hooker (1880) described the species $P$. erratica based on materials collected from India (Sikkim Himalayas, Assam), Nepal and Bhutan, under which he had also 
recognized two varieties namely var. latifolia and var. pedunculata. He distinguished the latter on the basis of its axillary cyme with $1-2$ inches $(2.5-5 \mathrm{~cm})$ long peduncle. This variety was described exclusively on the basis of plant materials collected by Nathaniel Wallich from Nepal. However, Deb \& Gangopadhyay (1989.) in their taxonomic revision on the genus Psychotria listed four more collections housed at CAL under specimens examined, two from Sikkim (G. King s.n., Persons s.n.) and the two other from Bhutan (G. King s.n., W.R. Jacob 257) and distinguished var. pedunculata from the typical variety on the basis of nature of inflorescence and indumentum on leaf surface and stipule.

In India, this variety is hitherto known to occur only in Sikkim, and therefore, the present collection from NSMPCA exhibits its extended distribution in West Bengal. Thorough explorations in adjacent regions are necessary to quantify its population and extend of occurrence.

3. Peliosanthes violacea Wall. ex Baker var. minor Baker, J. Linn. Soc., Bot. 17: 504. 1880. P. bakeri Hook.f., F1. Brit. India 6: 267. 1892. [ASPARAGACEAE]. [PLATE - I, Figure 3 a - c]

Rhizomatous herb, with strong fibrous roots, $10-15 \mathrm{~cm}$ long, ash coloured. Leaves narrowly elliptic or lanceolate, $14.5-18.5 \times 3.3-5 \mathrm{~cm}$, entire, acuminate, narrowly cuneate at base, glabrous; longitudinal parallel veins $10-19$; secondary veinlets less prominent; petioles subterete or flat, $15-24 \mathrm{~cm}$ long, rigid, glabrous. Racemes shorter than petiole, $11-16 \mathrm{~cm}$ long; scapes $3-4.5 \mathrm{~cm}$ long. Flowers $61-75$; pedicels $c .5 \mathrm{~mm}$ long; bracts lanceolate, membranous, $4-6 \times 1-2 \mathrm{~mm}$, equal or shorter then flower. Perianth $3-5 \mathrm{~mm}$ long, purple or pale white; tube $2-3 \mathrm{~mm}$ long, mostly adnate to ovary; lobes ovate-obconical, c. $1.5 \times 1.5 \mathrm{~mm}$. Corona ovoid-rounded, c. $2 \mathrm{~mm}$ long, purple. Fruits ovoid-globoid, $7-14 \times 5-9 \mathrm{~mm}$, glabrous; seeds ovoid, $0.6-13 \mathrm{~mm}$ long.

Flowering \& Fruiting: September - January.

Habitat: Found occasionally in moist shaded localities near streams in deciduous forests; growing with Chromolaena odorata (L.) R.M. King \& H. Rob., Curculigo orchioides Gaertn., Cyclea peltata (Lam.) Hook.f. \& Thomson, Cyathula prostrata (L.) Blume, Desmodium heterocarpon (L.) DC., Lepidagathis incurva Buch.-Ham. ex D. Don, Piper betleoides DC., P. lonchites Roem. \& Schult. and Spermacoce pusilla Wall.

Distribution: Endemic. India: Assam (Cachar hills), Meghalaya (Khasi and Garo hills) and West Bengal.

Specimen examined: India: West Bengal, Darjeeling district, North Sevoke MPCA, 177 m, 24.10.2017, K. Ravikumar \& N. Dhatchanamoorthy 120381 (FRLH).

Note: According to Roy (2018), it is an endemic species confined to Assam (Cachar) and Meghalaya (Khasi hills). However, the present record of its occurrence from NSMPCA shows its extended distribution in West Bengal. Intensive survey in the entire northeastern region would reveal its exact range of distribution in India. This variety differs from other varieties in leaf size and number of longitudinal veins, slightly upward facing flowers and floral bract shorter than flowers.

\section{Acknowledgements}

The authors are thankful to Mr. Darshan Shankar, Vice Chancellor, University of Transdisciplinary Health Sciences and Technology, Bengaluru, for facilities and encouragement. 
They are grateful to Dr. J.T. Mathew, IFS, Additional Principal Chief Conservator of Forests; Mr. Jiju Jasper, DFO, Silviculture, Darjeeling and other forest officials of North Sevoke Medicinal Plant Conservation Area, West Bengal State Forest Department for granting permission and help during field surveys respectively. Thanks are also due to Dr. S. Gokul, TDU - FRLHT, Bengaluru for meticulously arranging the figure.

\section{LITERATURE CITED}

Bremekamp, C.E.B. 1959. New Ixora species from Bengal, Burma and the Nicobar Islands. Indian For. 85(7): 372 - 373.

Champion, H.G. \& Seth, S.K. 1968. A Revised Survey of Forest Types of India, Govt. of India Press, New Delhi, p. 404

Deb, D.B. \& Gangopadhyay, M. 1989. Taxonomic revision of the genus Psychotria (Rubiaceae) in India. J. Econ. Taxon. Bot. Addl. Ser. 7: 1 - 166.

Hooker, J.D. 1880. Rubiaceae, in The Flora of British India. Vol. 3. L. Reeve \& Co., London. pp. $17-210$.

Husain, T. \& Paul, S.R. 1989. Taxonomic studies on Indian species of the genus Ixora L. (Rubiaceae). J. Econ. Taxon. Bot. Addl. Ser. 6: 1- 205.

Jessop, J.P. 1976. A revision of Peliosanthes (Liliaceae). Blumea 23: 141 - 159.

Roy, D.K. 2018. Taxonomic investigation on Peliosanthes violacea complex (Asparagaceae) in northeast India. In: Borthakur, S.K.; Bawri, A. \& Nath, N. (eds.), Advances in Botanical Research in North East India. Eastern Book House, Panbazar, Guwahati. Pp. $136-144$. 